\title{
STUDY OF CLINICAL PROFILE AND OUTCOME OF 216 VICTIMS OF CHEST TRAUMA IN TERTIARY CARE CENTRE OF CENTRAL INDIA
}

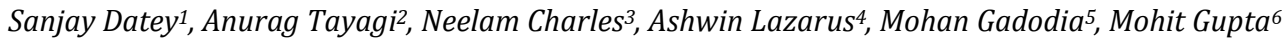 \\ 1 Professor, Department of General Surgery, Sri Aurobindo Medical College and Post Graduate Institute, Indore. \\ ${ }^{2}$ Senior Resident, Department of General Surgery, Sri Aurobindo Medical College and Post Graduate Institute, Indore. \\ 3 Professor, Department of General Surgery, Sri Aurobindo Medical College and Post Graduate Institute, Indore. \\ ${ }_{4}^{4} 2^{\text {nd }}$ Year Surgery Resident, Department of General Surgery, Sri Aurobindo Medical College and Post Graduate Institute, Indore. \\ 52 $2^{\text {nd }}$ Year Surgery Resident, Department of General Surgery, Sri Aurobindo Medical College and Post Graduate Institute, Indore. \\ ${ }^{6} 3^{\text {rd }}$ Year Surgery Resident, Department of General Surgery, Sri Aurobindo Medical College and Post Graduate Institute, Indore.
}

\begin{abstract}
This observational study of 216 victims of chest injuries was carried out at Sri Aurobindo Medical College and Postgraduate Institute of Indore (India). The study was conducted from $1^{\text {st }}$ January 2010 to $30^{\text {th }}$ June 2014 in the Department of Surgery at Sri Aurobindo Medical College and Postgraduate Institute, Indore. Polytrauma is recognized as the leading cause of death and disability in first four decades of life and the third most common cause of death. Chest is the central portion of body which contains vital organs of utmost importance. As chest is a large and exposed portion, it is vulnerable to impact injuries which are frequently life threatening. This study was carried out to quantify the problem of chest injuries in the population at large with special reference to various clinical presentations and outcome of management at our centre. Although blunt and penetrating injuries both were included in the study, but blunt injuries were commoner (82.4\%). Road traffic accident was responsible for $57.4 \%$ cases. A total of 120 patients out of 216 (55.5\%) were between 21 to 40 years of age. More than eighty percent victims were males. Musculoskeletal injuries (Long bone fractures etc.)) were the most common associated injuries. Twenty six (22.23\%) out of 216 died due to their injuries or complications. Twenty five percent were managed conservatively and were discharged in a satisfactory condition. One hundred and fifty nine needed thoracostomy, the commonest operative intervention. Overall outcome of chest injuries largely depends on magnitude and location of concomitant injuries. Prompt diagnosis of problem and immediate surgical intervention are the most important factors in the efficient management of chest injuries.
\end{abstract}

KEYWORDS: Chest Injuries, Road Traffic Accidents.

HOW TO CITE THIS ARTICLE: Sanjay Datey, Anurag Tayagi, Neelam Charles, Ashwin Lazarus, Mohan Gadodia, Mohit Gupta. "Study of Clinical Profile and Outcome of 216 Victims of Chest Trauma in Tertiary Care Centre of Central India." Journal of Evolution of Medical and Dental Sciences 2015; Vol. 4, Issue 93, November 19; Page: 15843-15847,

DOI: $10.14260 /$ jemds/2015/2297.

INTRODUCTION: Victims of chest trauma are increasing worldwide as the overall incidence of polytrauma is on the rise. Chest or the thoracic cavity forms the central portion of the body and is vulnerable to injury in any accident involving the upper or the lower portions of the body. These injuries can be minor bumps or trivial scratches to severe crushing or fatal penetrating trauma.

Polytrauma is recognized as a serious public health problem. In fact, it is the leading cause of death and disability in the first four decades of life and is the third most common cause of death overall. Isolated chest injuries or as a part of polytrauma constitute about $25 \%$ of all cases of trauma. Better economic growth with increasing use of fast moving automobiles which is responsible for vehicular accidents is the leading cause of polytrauma. Weapons are easily available and crimes of passion are on the rise with change in the social fabric. All these factors are responsible for the increasing number of polytrauma. Isolated chest injuries or as a part of polytrauma constitutes about $25 \%$ of all cases of trauma. The most common blunt thoracic injury is a rib fracture.

Financial or Other, Competing Interest: None.

Submission 17-10-2015, Peer Review 19-10-2015,

Acceptance 09-11-2015, Published 18-11-2015.

Corresponding Author:

Dr. Sanjay Datey,

43, Chikitsak Nagar,

Indore-452010, Madhya Pradesh.

E-mail: datesanjai@rediffmail.com

DOI:10.14260/jemds/2015/2297.
It is frequently associated with other injuries such as flail chest, pulmonary contusion, pneumothorax and hemothorax. The outcome of thoracic injuries depends upon the health care provider's knowledge of the physics of the event and urgency of the diagnosis, as well as the ability to assess and manage all the variables involved. The proper approach to the patient can positively influence the long-term outcome.

Thoracic cage contains the most vital organs - heart, lungs and the great vessels and it has to give protection to the vital organs as well as preserve the unique function of expansion of lungs to ensure proper oxygenation of blood. Although, the ribs sternum and vertebral column which form this sturdy but pliable rib cage gives enough protection, there are certain weak points in this structure like the intercostal spaces, angles of ribs and costochondral junctions.

These areas are more susceptible to trauma. As chest is a large and exposed portion, it is likely to get traumatized in most of the impact injuries.

In India trauma is becoming the leading cause of mortality and morbidity during the first four decades of life. The direct cost to society in caring to the needs of trauma victims is enormous and with majority of the patients affected being young individuals, their loss of productivity to the family and to the society is immense. We have done a study of all victims of chest trauma who were admitted in our hospital in last five and a half years. The demographic data, pattern of the accident and the clinical profile with the outcome of these 216 patients was analyzed. 
MATERIALS AND METHODS: This observational study was conducted in Sri Aurobindo Medical College and Post Graduate Institute of Indore, which has a tertiary care hospital catering to the Central India. Study was approved by the Institutional Ethics and Research committee. Study period was four and a half years between January 2010 to June 2014 and 216 patients of chest injuries were included. All patients of chest trauma who were admitted in the hospital were included in this study. The patients discharged against the medical advice were not included. Case records of all the patients were retrieved from the medical record department and studied. All the relevant information was entered in a proforma for each patient; a master chart made by entering the data. Tabulation and analysis was done by the Biostatician.

OBSERVATIONS: This study included 216 victims of chest trauma admitted to the hospital during 1st January 2010 to 30th June 2014. Table no. 1 shows the age wise distribution of the patients. Maximum number of patients belonged to the age group of 21 to 30, which comprised of 31.95 (69 out of 216). The second highest was between 31 to 40 , which was $51(23.6 \%)$. This shows that young people are more prone to chest trauma.

\begin{tabular}{|c|c|c|}
\hline $\begin{array}{c}\text { Age } \\
\text { (In Years) }\end{array}$ & $\begin{array}{c}\text { Number of } \\
\text { Patients }\end{array}$ & $\begin{array}{c}\text { Percentage } \\
(\%)\end{array}$ \\
\hline $1-10$ & 8 & 3.7 \\
\hline $11-20$ & 26 & 12 \\
\hline $21-30$ & 69 & 31.9 \\
\hline $31-40$ & 51 & 23.6 \\
\hline $41-50$ & 33 & 15.3 \\
\hline $51-60$ & 17 & 7.9 \\
\hline $61-$ above & 12 & 5.6 \\
\hline \multicolumn{3}{|c|}{$\begin{array}{c}\text { Table 1: Age wise Distribution } \\
\text { of Patients of Chest Trauma }\end{array}$} \\
\hline
\end{tabular}

\begin{tabular}{|c|c|c|}
\hline Sex & $\begin{array}{c}\text { Number of } \\
\text { Patients }\end{array}$ & $\begin{array}{c}\text { Percentage } \\
\text { (\%) }\end{array}$ \\
\hline Male & 174 & $81 \%$ \\
\hline Female & 42 & $19 \%$ \\
\hline \multicolumn{2}{|c|}{ Table 2: Sex Distribution of Patients } \\
\hline
\end{tabular}

Table no. 2 shows that 174 males and 42 females suffered chest trauma in this study. The relatively low incidence (19.45\%) can be explained on the basis that females are less exposed to external environment as compared to males.

\begin{tabular}{|c|c|c|}
\hline $\begin{array}{c}\text { Mechanism } \\
\text { of Injury }\end{array}$ & $\begin{array}{c}\text { Number of } \\
\text { Patients }\end{array}$ & $\begin{array}{c}\text { Percentage } \\
\text { (\%) }\end{array}$ \\
\hline Road traffic accident & 124 & $57.4 \%$ \\
\hline Fall from height & 45 & $20.8 \%$ \\
\hline Assault & 31 & $14.4 \%$ \\
\hline Industrial accident & 9 & $4.2 \%$ \\
\hline Hit by an animal & 7 & $3.2 \%$ \\
\hline \multicolumn{2}{|c|}{ Table 3: Mechanism of Injury in } \\
Patients of Chest Trauma (N=216) \\
\hline
\end{tabular}

Table no. 3 denotes the various modes of trauma in which road traffic accidents are the commonest. In our study 114 out of 216 (57.4\%) were due to road traffic accidents. Other reasons for chest trauma included fall from height $(20.8 \%)$, assault $(14.4 \%)$, industrial accident $(4.2 \%)$ and hit by animal in 7 patients (3.2\%), out of total 216 cases, studied in our series.

\begin{tabular}{|c|c|c|}
\hline $\begin{array}{c}\text { Type of } \\
\text { Injury }\end{array}$ & $\begin{array}{c}\text { Number of } \\
\text { Patients }\end{array}$ & $\begin{array}{c}\text { Percentage } \\
\text { (\%) }\end{array}$ \\
\hline Blunt trauma & 178 & $82.4 \%$ \\
\hline Penetrating trauma & 38 & $17.6 \%$ \\
\hline \multicolumn{2}{|c|}{ Table 4: Type of Chest Trauma (N=216) } \\
\hline
\end{tabular}

Table no. 4 shows that blunt chest trauma $(82.4 \%)$ is commoner than the penetrating trauma (17.6\%).

\begin{tabular}{|c|c|c|}
\hline $\begin{array}{l}\text { Type of } \\
\text { Injury }\end{array}$ & $\begin{array}{l}\text { Number of } \\
\text { Patients }\end{array}$ & $\begin{array}{c}\text { Percentage } \\
(\%)\end{array}$ \\
\hline Rib fracture & 147 & $68 \%$ \\
\hline Sternal fracture & 4 & $1.8 \%$ \\
\hline Pneumothorax & 96 & $44.4 \%$ \\
\hline Hemothorax & 67 & $31 \%$ \\
\hline Hemopneumothorax & 39 & $18 \%$ \\
\hline Lung contusion & 38 & $17.6 \%$ \\
\hline Flail chest & 5 & $2.3 \%$ \\
\hline Diaphragmatic injury & 2 & $1 \%$ \\
\hline Cardiac injury & 2 & $1 \%$ \\
\hline \multicolumn{3}{|c|}{$\begin{array}{l}\text { Table 5: Various Clinical Types in } \\
\text { Chest Trauma Victims }(N=216)\end{array}$} \\
\hline
\end{tabular}

Table no. 5 indicates that rib fractures are the commonest type of chest injuries. Out of the internal thoracic organs lung was injured in significant number of cases leading to only pneumothrax in $44.4 \%$, hemopneumothorax in $18 \%$ and lung contusions in 38 patients $(17.6 \%)$. Thirty nine patients out of $216(18 \%)$ had a hemothorax probably due to chest wall injury with a tear of vessel, sternal fractures (5), flail chest (4), cardiac injury (2) and diaphragmatic injuries were uncommon.

\begin{tabular}{|c|c|c|}
\hline $\begin{array}{l}\text { Associated } \\
\text { Injury }\end{array}$ & $\begin{array}{l}\text { Number of } \\
\text { Patients }\end{array}$ & $\begin{array}{c}\text { Percentage } \\
(\%)\end{array}$ \\
\hline Head injury & 52 & $24 \%$ \\
\hline Musculoskeletal injury & 58 & $26.8 \%$ \\
\hline Abdomen/pelvis & 19 & $8.7 \%$ \\
\hline Spinal injury & 7 & $3.2 \%$ \\
\hline \multicolumn{3}{|c|}{ Table 6: Associated Injuries ( $\mathrm{N}=216)$} \\
\hline
\end{tabular}

Table no. 6 shows the number of associated injuries in 216 patients of chest trauma in the study. Polytrauma patients have multiple injuries in which either the upper body or the lower body suffers the brunt of the injury, but the region of chest can be involved in association with either of them as it comes in the middle. Fifty eight patients had musculoskeletal injuries, mostly fractures of long bones and 52 had head injury. Abdominal and pelvic trauma was associated with chest trauma in 19 patients out of 216.

\begin{tabular}{|c|c|c|}
\hline $\begin{array}{l}\text { Clinical } \\
\text { Features } \\
\end{array}$ & $\begin{array}{c}\text { Number of } \\
\text { Patients }\end{array}$ & $\begin{array}{c}\text { Percentage } \\
(\%)\end{array}$ \\
\hline Pain in chest wall & 202 & $93.5 \%$ \\
\hline Respiratory distress & 181 & $83.8 \%$ \\
\hline Decreased breath sounds & 164 & $75.9 \%$ \\
\hline Surgical emphysema & 69 & $31.9 \%$ \\
\hline Hemoptysis & 6 & $2.7 \%$ \\
\hline Hypotension & 43 & $19.9 \%$ \\
\hline \multicolumn{3}{|c|}{$\begin{array}{l}\text { Table 7: Clinical Features in } \\
\text { Chest Trauma Victims }\end{array}$} \\
\hline
\end{tabular}


Table no. 7 shows the common symptoms and signs on clinical evaluation of the patients of chest trauma in this study. Pain and tenderness of the chest wall (93.5\%) was the commonest finding which is seen in cases of fractures of ribs. Difficulty in breathing due to severe pain in chest wall or respiratory distress $(83.8 \%)$ due to a pneumo or hemothorax was the second most common finding.

\begin{tabular}{|c|c|c|}
\hline Number of Days & $\begin{array}{c}\text { Number of } \\
\text { Patients }\end{array}$ & $\begin{array}{c}\text { Percentage } \\
\text { (\%) }\end{array}$ \\
\hline $1-10$ & 92 & $42.6 \%$ \\
\hline $11-20$ & 77 & $35.6 \%$ \\
\hline $21-30$ & 27 & $12.5 \%$ \\
\hline $31-40$ & 15 & $7 \%$ \\
\hline $41-50$ & 3 & $1.4 \%$ \\
\hline 51 -above & 2 & $1 \%$ \\
\hline \multicolumn{2}{|c|}{ Table 8: Duration of Hospital Stay } \\
\hline
\end{tabular}

Table no. 8 shows the number of days patients of chest trauma stayed in the hospital. Largest number of patients $(42.6 \%)$ stayed in the hospital for less than 10 days. Average stay was 11.14 days in the hospital. Out of the 216 cases, 164 were admitted in the intensive care unit while 52 were admitted to the ward. The maximum stay was 24 days while the average stay was 3.7 days in the intensive care unit.

\begin{tabular}{|c|c|c|}
\hline Treatment & $\begin{array}{c}\text { Number } \\
\text { of } \\
\text { Patients }\end{array}$ & $\begin{array}{c}\text { Percentage } \\
\text { (\%) }\end{array}$ \\
\hline Conservative & 54 & $25 \%$ \\
\hline Intercostal drainage & 159 & $73.6 \%$ \\
\hline Thoracotomy & 2 & $0.93 \%$ \\
\hline $\begin{array}{c}\text { Laparotomy for } \\
\text { diaphragmatic injury }\end{array}$ & 1 & $0.47 \%$ \\
\hline \multicolumn{2}{|c|}{$\begin{array}{c}\text { Table 9: Treatment Given to } \\
\text { Chest Trauma Patients }\end{array}$} \\
\hline
\end{tabular}

Table no. 9 shows the type of treatment given to the patients. Fifty four out of 216 (25\%) needed only conservative management whereas in 162 patients operative treatment was needed. The most common procedure in the management of chest injuries was intercostal drainage.

\begin{tabular}{|c|c|c|}
\hline Outcome & $\begin{array}{c}\text { Number of } \\
\text { Patients }\end{array}$ & $\begin{array}{c}\text { Percentage } \\
\text { (\%) }\end{array}$ \\
\hline $\begin{array}{c}\text { Discharged after } \\
\text { treatment }\end{array}$ & 48 & $22.23 \%$ \\
\hline $\begin{array}{c}\text { Discharged after } \\
\text { operative treatment }\end{array}$ & 142 & $65.74 \%$ \\
\hline Death due to injury & 26 & $12.03 \%$ \\
\hline Table 10: Outcome of Chest Trauma Patients (N=216) \\
\hline
\end{tabular}

Table no 10 depicts the outcome of chest trauma in this study of 216 patients. Twenty six (12.03\%) patients died due to their injuries. One hundred and ninety patients were discharged in a satisfactory condition either after a conservative treatment (48) and operative treatment (142).

Total 26 patients died in this series of 216. All patients were of polytrauma with different injuries, chest injury was present in all. Head injury is the commonest in the mortality cases.

DISCUSSION AND REVIEW OF LITERATURE: We have reviewed the available literature to update the information about the pathophysiology, diagnostic modalities and recent concepts of treatment of various chest injuries. Blunt or a penetrating injury can traumatize any one or multiple components of the thoracic cage or internal organs at a time. We have described the salient features of various injuries in tabular form, but the actual patient may have multiple problems in a given clinical scenario and the treatment will be executed as per the priority.

Various parts of the chest wall and internal organs, common types of trauma, available investigations and management options are described in a tabular form. Overall prognosis of all the injuries will depend upon various factors like age of the patient, severity, time interval between trauma and treatment, severity of associated injuries etc.

Tabular description of chest injuries:

\begin{tabular}{|c|c|c|c|}
\hline $\begin{array}{l}\text { Clinical } \\
\text { Condition }\end{array}$ & $\begin{array}{l}\text { Common } \\
\text { Causes }\end{array}$ & $\begin{array}{c}\text { Diagnostic } \\
\text { Investigations }\end{array}$ & Treatment \\
\hline Rib fractures & $\begin{array}{l}\text { Direct or } \\
\text { indirect } \\
\text { trauma }\end{array}$ & $\begin{array}{l}\text { X-ray chest, } \\
\text { Sonography, } \\
\text { CT scan }\end{array}$ & $\begin{array}{l}\text { Conservati } \\
\text { ve with } \\
\text { pain killers }\end{array}$ \\
\hline Flail chest & $\begin{array}{c}\text { Direct } \\
\text { trauma, } \\
\text { Run over } \\
\text { by a } \\
\text { vehicle }\end{array}$ & $\begin{array}{l}\text { X-ray, CT scan, } \\
\text { rule out } \\
\text { contusion of } \\
\text { lung }\end{array}$ & $\begin{array}{l}\text { Conservati } \\
\text { ve with } \\
\text { ventilatory } \\
\text { support. } \\
\text { Operative } \\
\text { in some } \\
\text { cases }\end{array}$ \\
\hline $\begin{array}{l}1^{\text {st }} \text { or/and } 2^{\text {nd }} \\
\text { rib fractures }\end{array}$ & $\begin{array}{l}\text { Direct } \\
\text { Excessive } \\
\text { force }\end{array}$ & $\begin{array}{l}\text { X-ray, CT Scan, } \\
\text { investigate for } \\
\text { associated } \\
\text { injuries } \\
\end{array}$ & $\begin{array}{c}\text { Pain } \\
\text { control, } \\
\text { pulmonary } \\
\text { toilet }\end{array}$ \\
\hline $\begin{array}{l}\text { Clavicular } \\
\text { fractures }\end{array}$ & $\begin{array}{c}\text { Falls on } \\
\text { outstretch } \\
\text { ed hand, } \\
\text { Direct } \\
\text { blows }\end{array}$ & X-Ray & $\begin{array}{c}\text { Conservati } \\
\text { ve mainly, } \\
\text { Figure of } 8 \\
\text { bandage }\end{array}$ \\
\hline $\begin{array}{l}\text { Sternoclavicu } \\
\text { lar disruption }\end{array}$ & $\begin{array}{c}\text { Strong } \\
\text { lateral } \\
\text { compressi } \\
\text { ve force }\end{array}$ & $\begin{array}{l}\text { X-ray, anterior } \\
\text { dislocation is } \\
\text { commoner } \\
\text { than posterior }\end{array}$ & $\begin{array}{l}\text { Closed or } \\
\text { open } \\
\text { reduction, } \\
\text { Brachial } \\
\text { plexus } \\
\text { injury is } \\
\text { common } \\
\end{array}$ \\
\hline $\begin{array}{l}\text { Sternal } \\
\text { fractures }\end{array}$ & $\begin{array}{c}\text { Direct } \\
\text { force, } \\
\text { Blunt } \\
\text { cardiac } \\
\text { injury } \\
\text { should be } \\
\text { suspected }\end{array}$ & $\begin{array}{c}\text { X-Ray, CTscan, } \\
\text { Echocardiogra } \\
\text { phy }\end{array}$ & $\begin{array}{c}\text { Mainly } \\
\text { Conservati } \\
\text { ve, Open } \\
\text { reduction } \\
\text { only in } \\
\text { those who } \\
\text { get } \\
\text { unbearable } \\
\text { pain }\end{array}$ \\
\hline $\begin{array}{l}\text { Scapular } \\
\text { fractures }\end{array}$ & $\begin{array}{c}\text { Direct } \\
\text { crushing } \\
\text { force, run } \\
\text { over by } \\
\text { vehicle }\end{array}$ & $\begin{array}{c}\text { Associated } \\
\text { with other } \\
\text { serious injuries }\end{array}$ & $\begin{array}{l}\text { Conservati } \\
\text { ve }\end{array}$ \\
\hline $\begin{array}{l}\text { Scapulothoraci } \\
\text { c dissociation }\end{array}$ & $\begin{array}{l}\text { Also called } \\
\text { as flail } \\
\text { shoulder } \\
\end{array}$ & & \\
\hline
\end{tabular}

CHEST WALL DEFECTS: Traumatic asphyxia; compression of chest with closed glottis, no specific surgical therapy. Blunt diaphragmatic injuries leading to tears. 


\begin{tabular}{|c|c|c|c|}
\hline Pneumothorax & $\begin{array}{c}\text { Fracture } \\
\text { ribs, } \\
\text { barotrauma, } \\
\text { deceleration } \\
\text { injuries }\end{array}$ & X-ray, CT Scan & $\begin{array}{l}\text { Intercostal } \\
\text { drainage } \\
\text { under water } \\
\text { seal }\end{array}$ \\
\hline Hemothorax & $\begin{array}{l}\text { Laceration of } \\
\text { intercostal } \\
\text { artery in } \\
\text { fracture rib, } \\
\text { lacerations } \\
\text { of lung } \\
\text { parenchyma }\end{array}$ & $\begin{array}{l}\text { X Ray, CT Scan, } \\
\text { ultrasonography }\end{array}$ & $\begin{array}{c}\text { Tube } \\
\text { thoracostomy, } \\
\text { repeated } \\
\text { aspirations, } \\
\text { thoracotomy } \\
\text { for old clotted } \\
\text { collections }\end{array}$ \\
\hline $\begin{array}{c}\text { Open } \\
\text { Pneumothorax }\end{array}$ & $\begin{array}{l}\text { Mainly due } \\
\text { to } \\
\text { Penetrating } \\
\text { injuries, } \\
\text { Rarely blunt } \\
\text { injuries with } \\
\text { lacerations }\end{array}$ & $\begin{array}{l}\text { A chest wall } \\
\text { defect larger } \\
\text { than laryngeal } \\
\text { opening, }\end{array}$ & $\begin{array}{l}\text { Three way } \\
\text { occlusive } \\
\text { dressing, } \\
\text { closure of } \\
\text { chest wall } \\
\text { defect with } \\
\text { thoracostomy }\end{array}$ \\
\hline $\begin{array}{c}\text { Tension } \\
\text { pneumothorax }\end{array}$ & $\begin{array}{l}\text { Parenchymal } \\
\text { lung injury } \\
\text { with } \\
\text { continued } \\
\text { air leak. }\end{array}$ & $\begin{array}{c}\text { Clinical } \\
\text { diagnosis with } \\
\text { immediate } \\
\text { treatment }\end{array}$ & $\begin{array}{l}\text { Large bore } \\
\text { needle in } 2^{\text {nd }} \\
\text { intercostal } \\
\text { space in } \\
\text { midclavicular } \\
\text { line or tube } \\
\text { thoracostomy }\end{array}$ \\
\hline $\begin{array}{l}\text { Pulmonary } \\
\text { contusion }\end{array}$ & $\begin{array}{l}\text { Flail chest, } \\
\text { stove in } \\
\text { chest }\end{array}$ & $\begin{array}{l}\text { X-Ray, CT Scan, } \\
\text { Perfusion scan }\end{array}$ & $\begin{array}{l}\text { Conservative, } \\
\text { pulmonary } \\
\text { toilet, broad } \\
\text { spectrum } \\
\text { antibiotics } \\
\end{array}$ \\
\hline
\end{tabular}

\begin{tabular}{|c|c|c|c|}
\hline $\begin{array}{c}\text { Blunt } \\
\text { bronchial } \\
\text { injury }\end{array}$ & $\begin{array}{c}\text { Associated } \\
\text { with } \\
\text { contusion/lace } \\
\text { ration lung }\end{array}$ & $\begin{array}{l}\text { X ray chest, } \\
\text { CT Scan }\end{array}$ & $\begin{array}{l}\text { Pulmonary } \\
\text { toilet, } \\
\text { ventilatory } \\
\text { support }\end{array}$ \\
\hline $\begin{array}{l}\text { Blunt } \\
\text { esophage } \\
\text { al injury }\end{array}$ & $\begin{array}{l}\text { Associated } \\
\text { with } \\
\text { Mediastinal } \\
\text { injury }\end{array}$ & $\begin{array}{l}\text { Contrast X } \\
\text { ray, CECT } \\
\text { thorax }\end{array}$ & $\begin{array}{c}\text { Operative } \\
\text { repair in case } \\
\text { of } \\
\text { discontinuity }\end{array}$ \\
\hline $\begin{array}{l}\text { Pericardi } \\
\text { al injury }\end{array}$ & $\begin{array}{c}\text { Associated } \\
\text { with sternal } \\
\text { fractures }\end{array}$ & $\begin{array}{c}\text { CECT, } \\
\text { Echocardiogr } \\
\text { aphy } \\
\end{array}$ & $\begin{array}{c}\text { Pericardiocen } \\
\text { tesis in case } \\
\text { of effusion }\end{array}$ \\
\hline $\begin{array}{l}\text { Myocardi } \\
\text { al injury }\end{array}$ & $\begin{array}{c}\text { Associated } \\
\text { with sternal } \\
\text { fractures, Flail } \\
\text { chest }\end{array}$ & $\begin{array}{c}\text { Echocardiogr } \\
\text { aphy, Enzyme } \\
\text { studies, ECG, } \\
\text { Transoesopha } \\
\text { geal } \\
\text { ultrasound }\end{array}$ & $\begin{array}{c}\text { Conservative } \\
\text { management } \\
\text { with } \\
\text { ventilatory } \\
\text { and } \\
\text { circulatory } \\
\text { support }\end{array}$ \\
\hline $\begin{array}{c}\text { Thoracic } \\
\text { duct } \\
\text { injury }\end{array}$ & $\begin{array}{l}\text { Chylous } \\
\text { effusions, } \\
\text { empyema }\end{array}$ & $\begin{array}{l}\text { Special dye } \\
\text { studies, } \\
\text { CECT/MRI }\end{array}$ & $\begin{array}{c}\text { Operative } \\
\text { intervention } \\
\text { for ligation } \\
\text { may be } \\
\text { needed }\end{array}$ \\
\hline
\end{tabular}

Trauma has been described to have notorious tendency to affect young males in the productive period of life.(1) Young males are more prone to chest trauma because of the greater exposure to external environmental forces in their daily activities. In this study, it was found that 31.95 patients of chest trauma were between 21 to 30 years. More than half of the patients (55.5\%) were between 21 to 40 years. M. Mohta et al.,(2) reported $49.55 \%$ patients in their study of 105 in the same age group (21-40 years). Massaga et al.(3) had $43.75 \%$ patients from age group of 30 to 49 years. The highest incidence in this age group can be attributed to the active lifestyle with exposure to factors like use of automobiles, working with machinery, assaults and contact sports.
Male preponderance was noted in our study with incidence of $80.55 \%$ patients, the relatively low incidence of females ( 42 out of 216) can be explained on the basis that females are less exposed to external factors. Other studies have shown similar findings. Monafishha et al.(4) reported male incidence of 79.35 in the study of 150 cases. In the study by M. Mohta et al.,(2) 95 out of 105 patients of chest trauma were males.

Motor vehicle accidents accounted for more than half $(57.45 \%)$ of all the injuries. F. A. Massaga et al., reported that $72.3 \%$ cases were due to vehicular accidents.(3) In a study of 1164 patients of chest trauma by Veysi et al.,(5) $57.01 \%$ cases were due to automobile accidents. Automobile accidents are major causes of polytrauma. Most of the victims suffer chest injuries when they are involved in polytrauma, rapid industrialization, higher rates of economic growth and better living standards have increased the use of high speed automobiles in our country. Our roads are not so good for such vehicles. Rules and regulations regarding safety are not followed stringently. Morbidity and mortality is going to increase in coming days which will be a serious medical and socioeconomical problem.

Ibrahim et al.(6) have reported incidence of 41\% (365 out of 888) cases due to assault. Probably the study was conducted in a troubled area as no other study has similarly higher incidence. Our study had $14.4 \%$ cases and Veysi et al.(5) had only $10.06 \%$ cases due to assault.

Most of the patients (82.4\%) suffered blunt injuries, similar to many other studies. M. Mohta et al.,(2) reported 785 of the patients out of 105 suffered blunt injuries in their study. Few studies have shown penetrating injuries to be the commonest cause of chest trauma. Nigerian study by Ali and Gali.(7) showed penetrating injury occurred in $61.5 \%$ of cases and these were mainly due to the civil wars and trauma by bandits. In a study by Maxwell.(8) penetrating injuries accounted for $77 \%$ of cases.

Symptomatology of chest trauma varies. Although it becomes easier to diagnose and manage a case of isolated chest trauma than in a patient who is unconscious due to head injury. In our study pain in chest (93.5\%) and respiratory distress $(83.8 \%)$ were the commonest clinical features. In our study musculoskeletal (26.8\%) and head injuries $(24 \%)$ were the commonest associated injuries. Nineteen patients suffered from abdominal and pelvic injuries and seven patients had spinal injuries. Monafisha et al.(7) had $33.3 \%$ cases of head injury and $26.7 \%$ cases of musculoskeletal injuries in their study of 105 cases. The associated injuries are related to the cause of injury as road traffic accidents always lead to multiple injuries whereas assault lead to isolated injuries mostly (Ali and Gali et al. ${ }^{7}$ )

The type of associated injury affected the morbidity and mortality in our study with head injuries particularly having a poor outcome. The average duration of stay in the hospital was 11.14 days in our study. Monafisha et al.(4) reported average length of stay to be 13.17 days in their study. Hospital stay mainly increases due to associated injuries e.g. longest stay of 62 days was observed in one of our patients which was due to head injury. Majority of patients were treated conservatively with closed observation and thoracostomy. More than $3 / 4^{\text {th }}$ of the patients had thoracostomy done $(76.38 \%)$ while $22.23 \%$ of the patients were managed conservatively alone. 
S. Dalal et al.(9-3) reported that $90 \%$ of patients with thoracic injuries could be managed by tube thoracostomy. Many other studies have shown similar results. F.A.Massaga et al.(3) reported $56.3 \%$ of cases had tube thoracostomy done in their study.

Outcome of a victim of chest trauma depends on various factors. Morbidity and mortality varies with age of the patient and force and location of trauma. Associated injuries increase the risk of complications in patients with chest trauma. Delay in diagnosis and treatment and respiratory complications increase the mortality. Early recognition and management of associated injuries and complications is of paramount importance in reducing the morbidity and mortality.

\section{REFERENCES:}

1. Mefire AC, Pagbe JJ, Fokou M, Nguimbous JF, Guifo ML, Bahebeck J. Analysis of epidemiology, lesionstreatment and outcome of 354 consecutive cases of blunt and penetrating trauma to the chest in an African setting.S Afr J Surg 2010, 48(3)90-93.

2. Medha Mohta, P kumar, A Mohta, R Bhardwaj, A Tyagi, AK Sethi. Experiences with chest trauma: Where do we stand today. IJCCM 2006; 10:1, 25-28.

3. FA Massaga, M Mchembe. The pattern and management of chest trauma at Muhimbili national Hospital, Dar es Sallaam. East and Central african Journal of Surgery, Vol.15, No.1, Mar-Apr, 2010 pp.124-129.
4. Monafisha k Lema,Phillipo L Chalya,joseph B Mabula and Willium Mahalu. Pattern and outcome of chest injuries at Bugando Medical Centre in Northwestern Tanzania. Journal of Cardiothoracic Surgery 2011,6; 7 doi;10.1186/1749-8090-6-7.

5. Veysi VT, Nikolaou VS, Paliobeis C, Eftathopoulos N, Giannoudis PV. Prevalence of chest trauma, associated injuries and mortality; A level I trauma centre experience. Int Orthop.2009 Oct; 33950:1425-33.

6. Ibrahim Al-Koudmani, BassamDarwish, Kamal Al-Kateb and Yahia Taifous. Chest trauma experience over eleven year period at Al-Moussat university teaching hospitalDamascus: a retrospective review of 888 cases. Journal of Cardiothoracic Surgery 2012, 7:35doi; 10.1186/17498090-7-35.

7. Ali N,Gali BM. Pattern and management of chest injury in Maiduguri, Nigeria. Annals of African Medicine. 200413 ;(4);181-184.

8. RA Maxwell, DJ Campbell, TC Fabian, MA luchette, AJ kerwin, KA Davis, K Nagy, S Tisherman. Use of presumpive antibiotics following tube thoracostomy for traumatic pneumothorax in prevention of empyema and pneuminia-a multicenter trial. J Trauma, 48(2000), 742748.

9. S.dalal, Nityasha, M Vashisht, R Dahiya. Prevalence of chest trauma at an apex institute of North India; A retrospective study. The Internet journal of Surgery, 2008; 18(1):84-89s. 